\title{
AKTIVITAS ANTIBAKTERI EKSTRAK Sargassum plagyophyllum TERHADAP BAKTERI Listeria monocytogenes DAN Pseudomonas aeruginosa
}

\author{
Santhy Wisuda Sidauruk ${ }^{\star}$, N Ira Sari, Andarini Diharmi, Ilman Arif \\ Jurusan Teknologi Hasil Perairan Fakultas Perikanan dan Kelautan \\ Universitas Riau, Kampus Bina Widya Km 12,5 Simpang Baru Pekanbaru 28293 Riau \\ Telepon/Fax. (0761) 63266/(0761) 63279 \\ Diterima: 20 November 2020/Disetujui: 22 Maret 2021 \\ ${ }^{\star}$ Korespondensi: santhy.sidauruk@lecturer.unri.ac.id
}

Cara sitasi: Sidauruk SW, Sari NI, Diharmi A, Arif I. 2021. Aktivitas antibakteri ekstrak Sargassum plagyophyllum terhadap bakteri Listeria monocytogenes dan Pseudomonas aeruginosa. Jurnal Pengolahan Hasil Perikanan Indonesia. 24(1): 27-37.

\begin{abstract}
Abstrak
Bakteri Listeria monocytogenes dan Pseudomonas aeruginosa merupakan bakteri patogen yang harus dihambat atau dibunuh pertumbuhannya menggunakan senyawa antibakteri. Sargassum sp. merupakan salah satu jenis rumput laut cokelat yang memiliki komponen senyawa bioaktif yang dapat berperan sebagai antibakteri. Penelitian ini bertujuan untuk memperoleh komponen bioaktif dan aktivitas antibakteri ekstrak Sargassum plagyophyllum. Penelitian ini terdiri dari maserasi rumput laut S. plagyophyllum dan karakterisasi ekstrak yang meliputi screening fitokimia dan analisis antibakteri gram positif dan negatif pada konsentrasi ekstrak yang berbeda yaitu 2, 4, dan 6\% w/v. Ekstrak metanol S. plagyophyllum memiliki rendemen $1,32 \pm 0,04 \%$ dan mengandung senyawa bioaktif alkaloid, steroid, saponin, dan fenolik. Jika dilihat dari aktivitas antibakteri, diperoleh bahwa ekstrak S. plagyophyllum memiliki zona hambat terhadap bakteri gram positif (L. monocytogenes) dan bakteri gram negatif (P. aeruginosa), namun diameter penghambatan pertumbuhan bakteri gram negatif $(6,67 \pm 0,58 \mathrm{~mm})$ lebih besar dibandingkan dengan bakteri gram positif $(4,67 \pm 0,58 \mathrm{~mm})$ pada konsentrasi ekstrak tertinggi $(6 \%)$.
\end{abstract}

Kata kunci: bioaktif, fitokimia, L. monocytogenes, maserasi, P. aeruginosa, S. plagyophyllum

\section{Antibacterial Activity of Sargassum plagyophyllum Extract against Listeria Monocytogenes and Pseudomonas aeruginosa}

\begin{abstract}
Listeria monocytogenes and Pseudomonas aeruginosa are pathogenic bacteria that must be inhibited and killed using antibacterial compounds. Sargassum sp. is one of the type of brown seaweed having bioactive compound as antibacterial. The research was aimed to determine the bioactive compounds and antibacterial activities of Sargassum plagyophyllum extract. This research consisted of maceration and characterization of S. plagyophyllum which included phytochemical screening and gram positive and negative antibacterial analysis at different concentrations of extract $(2,4$, and $6 \% \mathrm{w} / \mathrm{v})$. Methanol extract of S. plagyophyllum had a yield of $1.32 \pm 0.04 \%$ and contained bioactive compounds such as alkaloids, steroids, saponins, and phenolics. Based on antibacterial activity, S. plagyophyllum extract had the inhibition zone both for gram positive bacteria (L. monocytogenes) and gram negative bacteria (P. aeruginosa). However, the inhibition zone of gram negative bacteria $(6.67 \pm 0.58 \mathrm{~mm})$ was greater than gram positive bacteria $(4.67 \pm 0.58 \mathrm{~mm})$ at the highest concentration of extract (6\%).
\end{abstract}

Keyword: bioactive, phytochemical, L. monocytogenes, maceration, P. aeruginosa, S. plagyophyllum 


\section{PENDAHULUAN}

Bakteri patogen, misalnya Listeria monocytogenes dan Pseudomonas aeruginosa, merupakan bakteri yang dapat menyebabkan penyakit pada manusia. Bakteri L. monocytogenes merupakan salah satu bakteri gram positif yang terdapat pada manusia dan hewan ternak penyebab penyakit melalui konsumsi makanan terkontaminasi terutama sering ditemukan pada ikan dan produk perikanan (Habibi 2017; Dwiyitno 2010). Bakteri L. monocytogenes merupakan salah satu bakteri foodborne disease yang menyebabkan penyakit listeriosis (Amagliani et al. 2004). Bakteri ini juga merupakan penyakit yang menyumbangkan tingkat kematian mencapai 20-30\% (Ariyanti 2010).

Bakteri $P$. aeruginosa merupakan salah satu bakteri gram negatif yang sering ditemukan pada flora normal kulit dan usus manusia (Jawetz 2007). Pratami et al. (2013) melaporkan bahwa bakteri $P$. aeruginosa banyak ditemukan akibat kontaminasi air tercemar yang digunakan untuk mencuci tangan. Purwani et al. (2012) menyatakan bahwa bakteri $P$. aeruginosa merupakan salah satu mikroorganisme perusak pangan yang dapat ditemukan pada ikan dan daging. Bakteri $P$. aeruginosa dilaporkan sebagai salah satu bakteri yang resisten terhadap antibiotik (Deni dan Pangalila 2019; Rukmono dan Zuraida 2013).

Kedua bakteri patogen tersebut perlu dihambat atau dibunuh pertumbuhannya menggunakan senyawa antibakteri. Senyawa antibakteri alami dapat ditemukan dari tanaman (Pratiwi et al. 2013). Senyawa antibakteri alami mempunyai efektivitas penghambatan pertumbuhan bakteri yang tinggi pada mikroba penyebab penyakit yang ditemukan dari makanan (Nursini 2005; Ibrahim et al. 2009).

Rumput laut merupakan salah satu contoh tanaman dari perairan laut yang memiliki komponen bioaktif potensial sebagai antibakteri. Kordi (2010) melaporkan bahwa rumput laut hijau, merah, ataupun cokelat merupakan sumber potensial senyawa bioaktif yang sangat bermanfaat bagi pengembangan 1) industri farmasi seperti antibakteri, antitumor, antikanker atau sebagai agen, dan
2) industri agrokimia terutama antifeedant, fungisida, dan herbisida (Bachtiar 2007). Rumput laut juga telah banyak dimanfaatkan oleh masyarakat pesisir sebagai obat luar, salah satunya sebagai bahan antiseptik alami (Kordi 2010).

Sargassum sp. merupakan salah satu rumput laut cokelat yang mengandung senyawa antioksidan dari metabolit sekundernya yaitu alkaloid, saponin, tanin, flavonoid, fenol, steroid, dan iodin yang berpotensi sebagai antimikroba (Dolorosa et al. 2017; Manivannan et al. 2011; Nasmia et al. 2016). Senyawa bioaktif pada Sargassum sp. juga berpotensi sebagai antijamur (Guedes et al. 2012) dan sebagai antivirus dari Sargassum sp. yang diekstrasi secara hidrolisis enzimatis (Hardouin et al. 2014).

Kandungan senyawa metabolit sekunder tersebut dapat diperoleh dengan cara ekstraksi. Edison et al. (2020) melaporkan bahwa metode ekstraksi dapat dilakukan dengan cara perendaman (maserasi) menggunakan pelarut organik seperti metanol, etanol, etil asetat, dan heksana. Keutamaan metode maserasi adalah tidak merusak senyawa-senyawa yang tidak tahan panas. Senyawa metabolit sekunder tersebut dapat diketahui melalui pengujian screening fitokimia (Setyowati et al. 2014). Kandungan senyawa metabolit sekunder yang akan dideteksi dari rumput laut S. plagyophyllum adalah komponen senyawa yang berpotensi sebagai antibakteri.

Penelitian mengenai S. plagyophyllum telah dilaporkan memiliki kandungan metabolit sekunder yang berfungsi sebagai antioksidan dan inhibitor tirosinasi (Dolorasa et al. 2017; Dolorosa et al. 2019). Rumput laut cokelat S. plagyophyllum juga berpotensi sebagai antibakteri, namun informasinya masih minim terutama efektivitasnya dalam penghambatan pertumbuhan bakteri gram positif ( $L$. monocytogenes) dan bakteri gram negatif ( $P$. aeruginosa), padahal kedua jenis bakteri tersebut merupakan bakteri patogen yang sering ditemukan dalam makanan. Oleh karena itu, penelitian mengenai aktivitas antibakteri dari S. plagyophyllum terhadap bakteri $L$. monocytogenes dan $P$. aeruginosa perlu dilakukan dengan tujuan untuk 
memperoleh komponen bioaktif dan aktivitas ekstrak S. plagyophyllum pada bakteri gram positif dan gram negatif.

\section{BAHAN DAN METODE Bahan dan Alat}

Bahan-bahan utama yang digunakan pada penelitian ini yaitu S. plagyophyllum kering yang diperoleh dari perairan pantai sepanjang Gunung Kidul, Yogyakarta. Bahan-bahan untuk ekstraksi dan analisis yaitu metanol (teknis), akuades, kloroform (Merck), $\mathrm{NH}_{4} \mathrm{OH}$ (Merck), $\mathrm{H}_{2} \mathrm{SO}_{4}$ (Merck), pereaksi dragendorf (Sigma Aldrich), pereaksi meyer (Sigma Aldrich), pereaksi Wagner (Merck), eter (Merck), $\mathrm{HCl}$ (Merck), asam asetat anhidrat, etanol (Merck), $\mathrm{FeCl}_{3}$ (Merck), Muller Hinton agar (Oxoid), dimethyl sulfoxide (Merck), bakteri L. monocytogenes dan bakteri $P$. aeruginosa yang diperoleh dari Laboratorium Mikrobiologi Pangan Ilmu dan Teknologi Pangan IPB. Alat-alat utama yang digunakan pada penelitian ini antara lain evaporator putar (IKA RV 10 basic, Jerman), peralatan gelas (Pyrex), inkubator (Memmert), kertas saring, ayakan 60 mesh, dan cawan petri.

\section{Metode Penelitian}

Penelitian ini terdiri dari maserasi rumput laut S. plagyophyllum dan karakterisasi ekstrak yang meliputi screening fitokimia dan analisis antibakteri gram positif dan negatif pada konsentrasi ekstrak.

\section{Maserasi rumput laut (Zainuddin 2006)}

Sampel S. plagyophyllum dikeringkan dengan cara dikering anginkan selama \pm 5 hari, selanjutnya sampel yang telah kering tersebut dilakukan penghalusan menggunakan alat pemadu (blender) dan diayak menggunakan ayakan 60 mesh. Hasil pengayakan diperoleh serbuk kering rumput laut. Serbuk kering rumput laut S. plagyophyllum sebanyak 300 $\mathrm{g}$ diekstraksi secara maserasi menggunakan larutan metanol dengan perbandingan 1:3 (b/v) dan direndam selama $3 \times 24$ jam di dalam ruangan gelap dan pada suhu ruang. Ekstrak cair disaring, hingga didapat ampas dan hasil penyaringan yaitu maserat. Maserat yang diperoleh kemudian dipekatkan menggunakan evaporator putar dengan suhu $40{ }^{\circ} \mathrm{C}$ hingga diperoleh ekstrak kental, kemudian ekstrak ditimbang dan dihitung rendemen dengan rumus sebagai berikut:

Rendemen $=$ berat ekstrak (g)/berat rumput laut $\mathrm{x} 100 \%$

Ekstrak S. plagyophyllum tersebut diuji screening fitokimia serta aktivitas antibakteri gram positif dan negatif.

\section{Screening fitokimia}

Ekstrak S. plagyophyllum dianalisis kandungan fitokimianya secara kualitatif untuk mendeteksi keberadaan senyawa alkaloid, flavonoid, steroid, saponin, dan fenol hidrokuinon.

\section{Alkaloid (Harborne 2006)}

Ekstrak sebanyak 0,1 g ditambahkan 10 $\mathrm{mL}$ kloroform dan ditambahkan beberapa tetes amonia. Fraksi kloroform dipisahkan dan diasamkan dengan beberapa tetes $\mathrm{H}_{2} \mathrm{SO}_{4}$ pekat. Fraksi asam diambil dan dibagi menjadi tiga tabung, kemudian ditambahkan pereaksi Dragendorf, Meyer, dan Wagner. Keberadaan alkaloid ditandai dengan terbentuknya endapan putih pada pereaksi Meyer, endapan merah pada pereaksi Dragendorf, dan endapan cokelat pada endapan pereaksi Wagner.

\section{Flavonoid (Harborne 2006)}

Ekstrak ditambahkan serbuk magnesium $0,1 \mathrm{mg}$ dan $0,4 \mathrm{~mL}$ amil alkohol (campuran asam klorida 37\% dan etanol 95\% dengan volume yang sama) dan $4 \mathrm{~mL}$ alkohol kemudian campuran dikocok. Pembentukan warna merah, kuning atau jingga pada lapisan amil alkohol menunjukkan hasil flavonoid.

\section{Steroid/Triterpenoid (Harborne 2006)}

Sebanyak $1 \mathrm{~g}$ ekstrak dilarutkan dengan $25 \mathrm{~mL}$ etanol panas $50^{\circ} \mathrm{C}$, kemudian disaring ke dalam pinggan porselen dan diuapkan sampai kering. Residu dilarutkan dengan eter dan dipindahkan ke dalam tabung reaksi, lalu ditambahkan 3 tetes asam asetat anhidrat dan 1 tetes $\mathrm{H}_{2} \mathrm{SO}_{4}$ pekat (Uji Lieberman Burchard). Warna merah atau ungu menunjukkan triterpenoid dan warna hijau atau biru menunjukkan steroid. 


\section{Saponin (Harborne 2006)}

Sebanyak 1 g ekstrak ditambah $20 \mathrm{~mL}$ akuades, selanjutnya dipanaskan selama 5 menit. Larutan kemudian disaring dan filtrat dimasukkan ke dalam tabung reaksi tertutup, selanjutnya dikocok kuat secara vertikal selama 10 detik. Adanya saponin ditandai dengan terbentuknya busa yang stabil selama 10 menit dan tidak hilang pada penambahan 1 tetes $\mathrm{HCl} 2 \mathrm{~N}$.

\section{Fenol hidrokuinon (Harborne 2006)}

Sebanyak $1 \mathrm{~g}$ ekstrak diekstrak dengan $20 \mathrm{~mL}$ etanol 70\%. Ekstrak sebanyak $1 \mathrm{~mL}$ kemudian ditambahkan 2 tetes larutan $\mathrm{FeCl}_{3}$ $5 \%$. Pembentukan warna hijau atau hijau biru menunjukkan senyawa fenol dalam ekstrak.

\section{Uji aktivitas antibakteri (Pratiwi 2008; Radji 2011)}

Ekstrak rumput laut yang dihasilkan diuji efektivitasnya sebagai antiseptik dengan metode well diffusion (difusi sumuran). Bakteri uji berupa bakteri gram positif dan bakteri gram negatif dikulturkan dengan metode lempeng tuang, dengan cara menuangkan suspensi bakteri tersebut sebanyak $100 \mu \mathrm{L}$ ke dalam cawan petri, kemudian ditambahkan Mueller Hinton Agar sebesar $20 \mathrm{~mL}$ dan dihomogenkan. Setelah media memadat dibuat well (sumuran) sebesar $5 \mathrm{~mm}$ pada media kultur, kemudian dimasukkan ekstrak S. plagyophyllum dengan konsentrasi 2, 4, dan $6 \%(\mathrm{w} / \mathrm{v})$. Kultur tersebut kemudian diinkubasi selama \pm 48 jam pada suhu $37^{\circ} \mathrm{C}$. Diameter zona hambat ditentukan sebagai berikut:

Zona hambat $=$ diameter zona hambat terbentuk $(\mathrm{mm})$ diameter sumur ( $\mathrm{mm})$

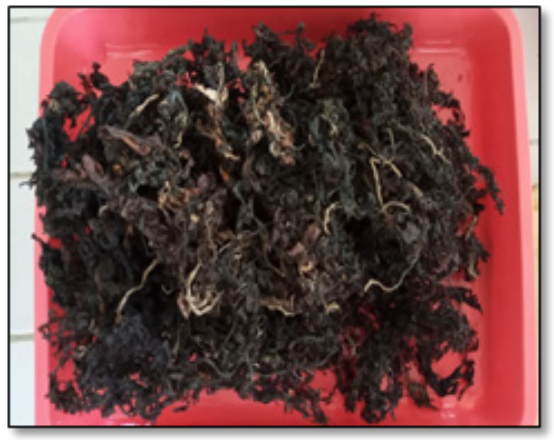

(A)

\section{Analisis Data}

Analisis nilai rendemen dan screening fitokimia dilakukan secara deskriptif menggunakan Microsoft Excel dan disajikan dalam bentuk diagram dan tabel. Rancangan percobaan hasil analisis aktivitas antibakteri gram positif dan gram negatif adalah rancangan acak lengkap (RAL). Perlakuan yang diberikan adalah konsentrasi ekstrak berbeda (2\%, 4\%, dan 6\%) dengan pengulangan sebanyak tiga kali ulangan setiap perlakuan. Data yang diperoleh dianalisis menggunakan Analysis of Variance (ANOVA) dengan tingkat kepercayaan $95 \%(\alpha=0,05)$ dan dilakukan uji lanjut Duncan.

\section{HASIL DAN PEMBAHASAN Ekstrak S. plagyophyllum}

Pengeringan rumput laut S. plagyophyllum dilakukan dengan cara dikeringanginkan bertujuan untuk menurunkan kehilangan komponen bioaktif pada rumput laut tersebut (Figure 1). Tapotubun (2018) menyatakan bahwa pengeringan rumput laut secara tidak langsung (dikeringanginkan) memiliki suhu yang lebih rendah yaitu $25-28{ }^{\circ} \mathrm{C}$ dibandingkan pengeringan sinar matahari (25-34 $\left.{ }^{\circ} \mathrm{C}\right)$ sehingga komposisi kimia pada rumput laut yang dikeringanginkan lebih tinggi dibandingkan dengan pengeringan sinar matahari. Masduqi et al. (2014) menyatakan bahwa rumput laut $S$. polycystum yang dikeringkan dengan metode kering angin memiliki senyawa fenol lebih tinggi $(1.656,3$ ppm) jika dibandingkan dengan pengeringan menggunakan oven (1.187,7 ppm).

Ekstraksi dilakukan secara maserasi dengan hasil yang diperoleh berbentuk pasta dan berwarna hijau kecokelatan. Warna

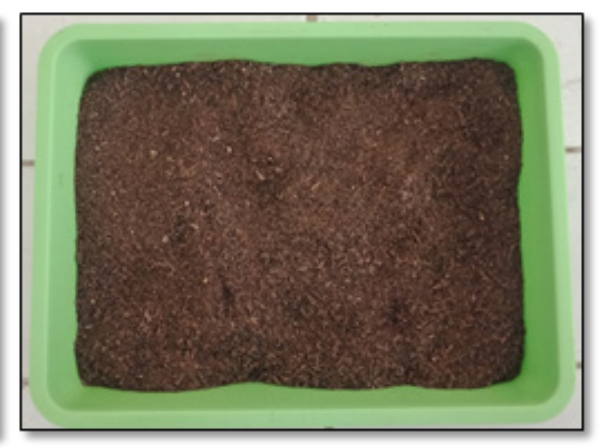

(B)

Figure 1 Dried S. plagyophyllum (A); Powdered S. plagyophyllum (B) 
hijau kecokelatan yang diperoleh disebabkan oleh adanya pigmen yang terkandung pada S. plagyophyllum. Limantara dan Heriyanto (2011) dan Firdaus (2011) menyatakan bahwa pigmen yang berperan dalam memberikan warna pada Sargassum sp. terdiri dari fukosantin (pigmen cokelat), karotenoid (pigmen merah), klorofil a (pigmen hijau kebiruan), dan xantofil. Park et al. (2007) menyatakan bahwa karotenoid merupakan pigmen larut lemak yang dapat terekstrak dalam pelarut organik seperti metanol.

Putra et al. (2014) menyatakan bahwa proses pengerjaan ekstraksi dengan metode maserasi lebih sederhana dan dilakukan pada suhu ruang sehingga terhindar dari kerusakan metabolit dalam sampel yang tidak stabil terhadap pemanasan. Proses maserasi rumput laut tersebut dilakukan dengan menggunakan larutan metanol. Andriani et al. (2015) menyatakan bahwa pelarut metanol merupakan pelarut terbaik untuk mengekstrak senyawa aktif rumput laut dengan senyawa aktif yang teridentifikasi yaitu triterpenoid, steroid, flavonoid, dan alkaloid yang berperan sebagai antibakteri. Hasil rendemen ekstrak dari hasil evaporasi dapat dilihat pada Table 1.

Table 1 Yield of Sargassum sp. extract

\begin{tabular}{lc}
\hline \multicolumn{1}{c}{ Solvent } & Yield (\%) \\
\hline Metanol & $1.320 \pm 0.04$ \\
n-heksan* & 0.133 \\
Etil asetat $^{*}$ & 0.027 \\
\hline
\end{tabular}

${ }^{*}$ Hidayat et al. (2018)

Hasil rendemen ekstrak menggunakan pelarut metanol lebih tinggi yaitu $1.32 \pm 0.04 \%$ jika dibandingkan dengan pelarutlain. Hidayat et al. (2018) melaporkan bahwa rendemen ekstrak n-heksan Sargassum sp. yaitu 0,133\%, sedangkan rendemen ekstrak etil asetat Sargassum sp. sebesar 0,027\%. Perbedaan hasil rendemen ekstrak tersebut dipengaruhi oleh jenis pelarut, metode ekstraksi, waktu ekstraksi, perbandingan bahan dan pelarut, suhu ekstraksi, ukuran sampel, dan lokasi habitat sampel (Kumar et al. 2012).

Menurut Siregar et al. (2012) menyatakan bahwa pelarut metanol memiliki rendemen yang lebih banyak dibandingkan dengan pelarut lainnya dikarenakan pelarut metanol dapat melarutkan metabolit yang bersifat polar dan nonpolar. Selain itu, pelarut metanol tersebut aman digunakan untuk formulasi sediaan topikal. Hidayat et al. (2018) melaporkan bahwa pelarut metanol pada ekstrak Sargassum sp. dan E. cottonii memiliki kemampuan menarik komponen aktif secara optimal jika dibandingkan dengan pelarut organik lainnya. Firdaus (2013) juga melaporkan bahwa ekstrak metanol Sargassum aquifolium memiliki aktivitas penghambatan radikal bebas paling besar dibandingkan ekstrak lainnya (etanol, aseton, dan akuades). Hal ini karena metanol sebagai pelarut polar ekstrak memiliki sifat mudah terjadi perpindahan proton (atom hidrogen) ekstrak ke radikal bebas.

\section{Kandungan Fitokimia}

Hasil analisis screening fitokimia ekstrak rumput S. plagyophyllum dapat dilihat pada Table 2. Screening fitokimia bertujuan untuk memberikan informasi jenis senyawa kimia yang terkandung dalam tumbuhan serta dapat memberikan efek fisiologis. Copriyadi et al. (2005) menyatakan bahwa komponen aktif sangat berguna untuk memprediksi manfaatnya bagi tubuh manusia. Table 2 Phytochemical content of S. plagyophyllum extract

\begin{tabular}{lc}
\hline \multicolumn{1}{c}{ Compound } & Results \\
\hline Alkaloids & + (White sediment $)$ \\
Meyer & + (Orange/brown) \\
Wagner & + (Orange/yellow) \\
Dragendroff & - (Red solution $)$ \\
Flavonoids & + (Blue/greenish color $)$ \\
Steroids & + (Formed foam $)$ \\
Saponins & + (Blue/purple solution) \\
Phenol hydroquinone &
\end{tabular}

Hasil analisis screening fitokimia secara kualitatif menunjukkan bahwa ekstrak S. plagyophyllum mengandung alkaloid, steroid, saponin, dan fenolik. Analisis alkaloid dengan pereaksi Meyer menunjukkan hasil positifkarenaterbentuknyakomplekskalsiumalkaloid yang mengendap sebagai akibat reaksi dari nitrogen pada alkaloid dan ion logam $\mathrm{K}^{+}$. Hasil uji alkaloid menggunakan pereaksi 
Wagner dan Dragendroff menunjukkan hasil positif dengan ditandai terbentuknya endapan cokelat hingga jingga (kalium-alkaloid) (Setyowati et al. 2014). Alkaloid merupakan metabolit sekunder pada tanaman yang berfungsi sebagai senyawa beracun untuk melindungi tanaman dari penyakit dan hama. Senyawa alkaloid juga merupakan senyawa kimia yang mengandung nitrogen bersifat basah yang banyak terdeteksi pada ekstrak pelarut polar dan larut dalam pelarut organik. Alkaloid memiliki aktivitas farmakologis dan berperan sebagai anti bakteri (Rohyani et al. 2015; Haryani et al. 2012).

Hasil uji steroid menunjukkan hasil positif dengan ditandai terbentuk warna biru kehijauan. Riwanti dan Izazih (2019) menyatakan bahwa identifikasi steroid dan terpenoid pada rumput laut cokelat S. polycystum ditandai dengan terbentuknya warna violet saat ditambahkan $\mathrm{H}_{2} \mathrm{SO}_{4}$ dan adanya terbentuk warna kuning yang menunjukkan terdapat steroid jenuh. Perubahan warna yang terjadi tersebut disebabkan adanya proses oksidasi pada golongan senyawa steroid melalui pembentukan ikatan rangkap terkonjugasi (Setyowati et al. 2014). Steroid dapat larut dalam pelarut organik (Nurjanah et al. 2011). Senyawa steroid dan turunan terpenoid berfungsi sebagai antibakteri dan antijamur (Rosyidah et al. 2010; Suptijah et al. 2013).

Hasil uji saponin menunjukkan hasil positif ditandai dengan terbentuknya busa. Terbentuknya busa pada uji saponin menunjukkan bahwa adanya glikosida yang dapat membentuk busa dalam air yang terhidrolisis menjadi glukosa dan senyawa lainnya (Setyowati et al. 2014). Senyawa saponin juga berpotensi sebagai antibakteri, antijamur dan antivirus (Mien et al. 2015). Hasil uji fenol hidrokuinon menunjukkan hasil positif ditandai dengan terbentuknya larutan biru atau ungu. Nurjanah et al. (2011) menyatakan bahwa perubahan warna hijau atau hijau biru pada larutan sampel menunjukkan bahwa terdapat senyawa fenol hidrokuinon pada larutan sampel tersebut. Reaksi pembentukan warna tersebut disebabkan oleh adanya reaksi antara ion hidroksil pada senyawa fenol dengan ion $\mathrm{FeCl}_{3}$
(Sangi et al. 2012). Thangaraju et al. (2012) melaporkan bahwa komponen fenolik pada rumput laut cokelat $S$. polycystum berpotensi sebagai antibakteri, antifungi, dan antikanker.

Yulianti dan Rakhmawati (2017) menyatakan bahwa senyawa metabolit sekunder pada alga laut (rumput laut) yang berpotensi sebagai antibakteri adalah flavonoid, tanin, saponin, dan steroid. Rumput laut cokelat memiliki aktivitas antibakteri dari golongan alkaloid, steroid, terpenoid (monoterpenoid, diterpenoid, dan triterpenoid), dan senyawa fenolik (senyawa pitol) (Grayson 2000; Lim et al. 2006).

\section{Aktivitas Antibakteri Gram Positif}

Daya hambat antibakteri gram positif terhadap bakteri L. monocytogenes pada ekstrak S. plagyophyllum disajikan pada Table 3. L. monocytogenes dapat diklasifikasikan sebagai bakteri gram positif berbentuk batang, pembentukan non-spora, dan anaerob fakultatif yang bertanggung jawab atas penyakit infeksi tertentu pada manusia (Robinson et al. 2000).

Table 3 Inhibition of gram positive bacteria (L. monocytogenes) in S. plagyophyllum extract

\begin{tabular}{cc}
\hline Concentration (\%) & Inhibition \\
\hline 2 & + \\
4 & + \\
6 & + \\
\hline
\end{tabular}

Table 3 menunjukkan bahwa ekstrak S. plagyophyllum memiliki daya hambat terhadap pertumbuhan bakteri L. monocytogenes baik pada konsentrasi 2, 4 maupun $6 \%$. Daya hambat tersebut ditandai dengan terbentuknya zona bening. Aktivitas antibakteri yang dihasilkan dilihat dari diameter zona hambat yang terbentuk $(\mathrm{mm})$ disajikan pada Figure 2.

Diameter zona hambat bakteri L. monocytogenes semakin besar seiring dengan pertambahan konsentrasi ekstrak S. plagyophyllum. Diameter zona hambat bakteri L. monocytogenes terbesar terdapat pada 6\% ekstrak S. plagyophyllum sebesar $4,67 \pm 0,58 \mathrm{~mm}$. Ekstrak 2, 4, dan $6 \%$ terbukti mampu menghambat pertumbuhan bakteri 


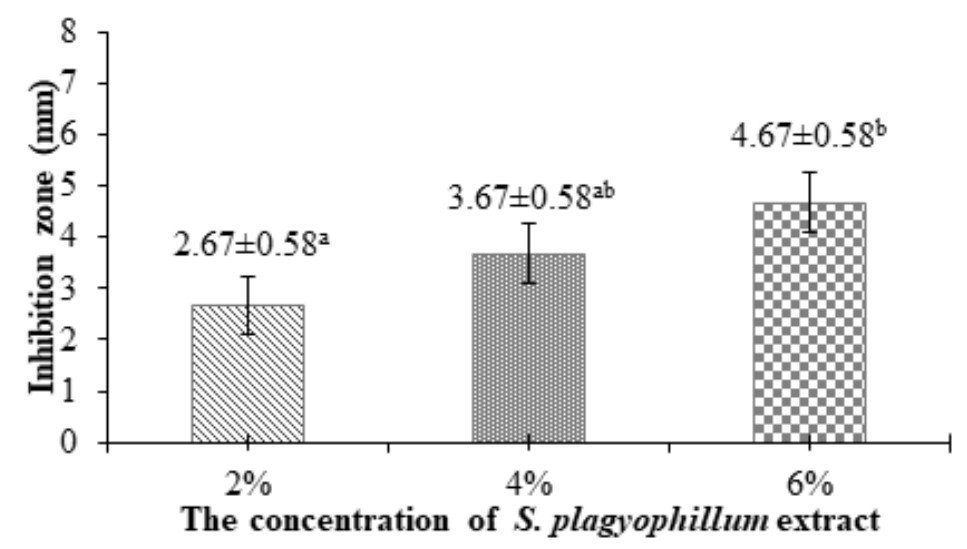

Figure 2 Activity of gram positive bacteria (L. monocytogenes) in S. plagyophillum extract

L. monocytogenes dengan terbentuknya zona bening berturut-turut $2,67 \pm 0,58 \mathrm{~mm}$, $3,67 \pm 0,58 \mathrm{~mm}$, dan $4,67 \pm 0,58 \mathrm{~mm}$. Tingkat penghambatan pertumbuhan bakteri ini termasuk kategori lemah. Pernyataan ini didukung oleh penelitian Davis dan Stout (1971) yang melaporkan bahwa jika zona hambat bakteri yang terbentuk berkisar kurang dari $5 \mathrm{~mm}$ memiliki tingkat penghambatan pertumbuhan bakteri yang lemah, jika zona hambat bakteri 5-10 $\mathrm{mm}$ dikategorikan sedang, 10-20 mm dikategorikan kuat, dan lebih dari $20 \mathrm{~mm}$ dikategorikan sangat kuat.

Zona hambatan yang terbentuk diduga karena ekstrak rumput laut tersebut memiliki kandungan senyawa bioaktif antibakteri, sehingga menghambat pertumbuhan bakteri uji. Rumput laut cokelat Sargassum memiliki kandungan biopigmen fukosantin. Fukosantin tersebut memiliki aktivitas antibakteri pada bakteri L. monocytogenes (Rajauria dan Ghannam 2013).

\section{Aktivitas Antibakteri Gram Negatif}

Bakteri Pseudomonas sp. memiliki karakteristik seperti gram negatif (Suyono dan Farid 2011). Bakteri P. aeruginosa merupakan bakteri patogen yang sering menyebabkan infeksi kulit pada manusia (Refdanita et al. 2004). Daya hambat antibakteri gram negatif terhadap bakteri $P$. aeruginosa pada ekstrak S. plagyophyllum disajikan pada Table 4.

Tabel 4 menunjukkan bahwa ekstrak S. plagyophyllum memiliki daya hambat terhadap pertumbuhan bakteri $P$. aeruginosa baik pada konsentrasi 2, 4 maupun 6\%. Penelitian ini sejalan dengan penelitian
Table 4 Inhibition of gram negative bacteria (P. aeruginosa) in S. plagyophyllum extract

\begin{tabular}{cc}
\hline Concentration (\%) & Inhibition \\
\hline 2 & + \\
4 & + \\
6 & + \\
\hline
\end{tabular}

Siregar et al. (2012) melaporkan bahwa Sargassum crassifolium memiliki zona hambat terhadap bakteri $P$. aeruginosa, sedangkan pada rumput laut Caulerpa racemosa dan E. cottonii tidak memiliki zona hambat terhadap bakteri $P$. aeruginosa. Daya hambat tersebut ditandai dengan terbentuknya zona bening. Ekstrak metanol Sargassum sp. memiliki efektivitas penghambatan pertumbuhan bakteri $P$. aeruginosa karena pada ekstrak tersebut mengandung senyawasenyawa metabolit sekunder misalnya saponin dan steroid yang berpotensi sebagai senyawa antibakteri (Yunianto et al. 2014).

Aktivitas antibakteri yang dihasilkan dilihat dari diameter zona hambat yang terbentuk $(\mathrm{mm})$ disajikan pada Figure 3.

Diameter zona hambat bakteri $P$. aeruginosa semakin besar seiring dengan pertambahan konsentrasi ekstrak S. plagyophyllum. Ketiga ekstrak terbukti mampu menghambat pertumbuhan bakteri $P$. aeruginosa dengan terbentuknya zona bening. Zona hambat bakteri yang terbentuk tersebut termasuk kategori sedang sesuai dengan penelitian Davis dan Stout (1971).

Jika dilihat dari zona hambat yang terbentuk, zona hambat yang terbentuk pada bakteri gram negatif ( $P$. aeruginosa) memiliki 


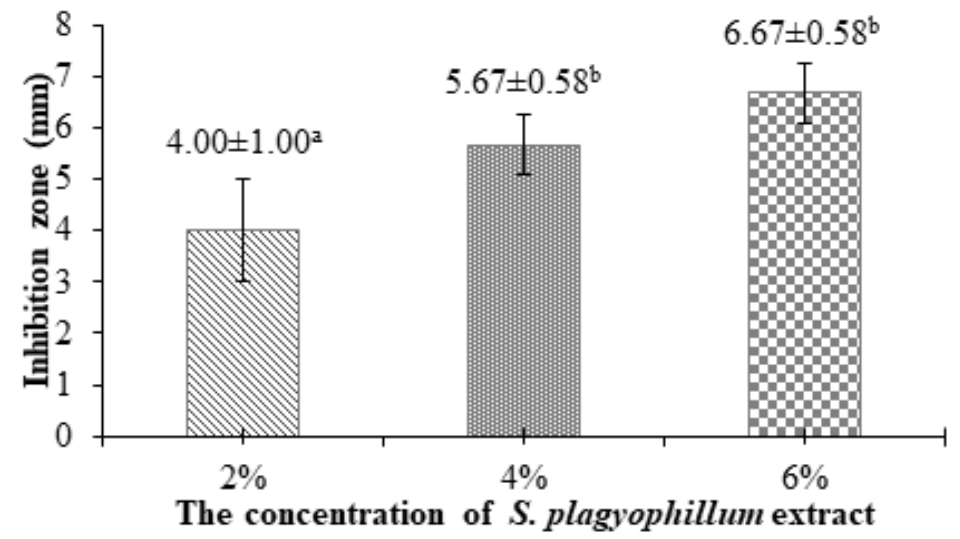

Figure 3 Activity of gram negative bacteria (P. aeruginosa) in S. plagyophyllum extract

diameter penghambatan yang lebih besar dibandingkan dengan zona hambat pada bakteri gram positif (L. monocytogenes). Hal ini disebabkan oleh bakteri gram negatif memiliki lapisan peptidoglikan yang lebih tipis berkisar 5-10 $\mathrm{nm}$ sehingga lebih mudah dirusak oleh komponen metabolit sekunder yang memiliki potensi menghambat sintesis dinding sel, sedangkan bakteri gram positif memiliki lapisan peptidoglikan lebih tebal berkisar $20-80 \mathrm{~nm}$ sehingga lebih sulit untuk dirusak oleh komponen metabolit sekunder (Sukmiwati et al. 2018).

Pelarut metanol (polar) yang digunakan dalam proses maserasi menghasilkan senyawa antimikroba yang bersifat polar akan memengaruhi efektivitas penghambatan bakteri gram negatif. Baehaki et al. (2018) melaporkan bahwa senyawa antimikroba yang bersifat polar lebih sensitif dalam penghambatan pertumbuhan bakteri gram negatif sehingga senyawa antibakteri bersifat polar akan lebih mudah terjadi proses lisis sel.

\section{KESIMPULAN}

Ekstrak S. plagyophyllum memiliki senyawa bioaktif alkaloid, steroid, saponin, dan fenolik. Senyawa-senyawa bioaktif tersebut berperan sebagai antibakteri. Jika dilihat dari aktivitas antibakteri, diperoleh bahwa ekstrak S. plagyophyllum memiliki zona hambat terhadap bakteri gram positif (L. monocytogenes) dan bakteri gram negatif $(P$ aeruginosa), namun diameter penghambatan pertumbuhan bakteri gram negatif lebih besar dibandingkan dengan bakteri gram positif.

\section{UCAPAN TERIMA KASIH}

Penulis mengucapkan terima kasih kepada Lembaga Penelitian dan Pengabdian Masyarakat Universitas Riau (LPPM UNRI) yang telah mendanai penelitian ini melalui DIPA LPPM UNRI 2020.

\section{DAFTAR PUSTAKA}

Amagliani G, Brandi E, Omiccioli A, Casiere IJ, Bruce, Magnani. 2004. Direct detection of Listeria monocytogenes from milk by magnetic based DNA isolation and PCR. Food Microbiology. 21(5): 597-603.

Andriani Z, Ghanaim F, Ahmad H. 2015. Antibacterial activity of the red Algae Eucheuma cottonii extract from Tanjung Coast, Sumenep Madura. Alchemy: Journal of Chemistry. 4(2): 93-100.

AriyantiT.2010.BakteriListeriamonocytogenes sebagai kontaminan makanan asal hewan (foodborne disease). Wartazoa. 20(2): 94102.

Bachtiar A. 2007. Penelusuran Sumber Daya Hayati Laut (Alga) Sebagai Biotarget Industri. [Makalah]. Jatinangor (ID): Fakultas Perikanan dan Ilmu Kelautan Universitas Padjadjaran.

Baehaki A, Herpandi H, Anggraini A. 2018. Aktivitas antibakteri ekstrak tumbuhan perairan kiambang (Salvinia molesta). Jurnal Sains dan Teknologi. 16(2): 125134.

Copriyadi J, Yasmi E, Hidayati. 2005. Isolation and characterization of coumarines from peels of orange (Citrus hystrix DC). Jurnal Biogenesis. 2: 13-25.

Davis WW, Stout TR. 1971. Disc plate methods 
of microbiological antibiotic assay. Applied Microbiology. 22(4): 659-665.

Deni J, Pangalila FJV. 2019. Hubungan keberhasilan terapi pneumonia nosokomial resisten Pseudomonas aeruginosa dan Acinetobacter baumannii dengan dosis Karbapenem di ICU RS Royal Taruma periode 2012-2017. Tarumanagara Medical Journal. 2(1): 6576.

Dolorosa MT, Nurjanah, Purwaningsih S, Anwar E, Hidayat T. 2019 Tyrosinase inhibitory activity of Sargassum plagyophyllum and Eucheuma cottonii methanol extracts. IOP Conference Series: Earth and Environmental Science. 278 (1): 1715-1375.

Dolorosa TM, Nurjanah, Purwaningsih S, Effionora A, Taufik H. 2017. Kandungan senyawa bioaktif bubur rumput laut Sargassum plagyophyllum dan Eucheuma cottonii sebagai bahan baku krim pencerah kulit. Jurnal Pengolahan Hasil Perikanan Indonesia. 20(3): 633-644.

Dwiyitno. 2010. Identifikasi bakteri patogen pada produk perikanan dengan teknik molekuler. Squalen. 5(2): 67-78.

Edison, Diharmi A, Ariani NM, Mirna Ilza. 2020. Komponen bioaktif dan aktivitas antioksidan ekstrak kasar Sargassum plagyophyllum. Jurnal Pengolahan Hasil Perikanan Indonesia. 23(1): 58-66.

Yulianti E dan Rakhmawati A. 2017. Screening and characterization of phosphate solubilizing bacteria from isolate of thermophilic bacteria. AIP Conference Proceeding. 1868(1): 090015.

Firdaus M. 2011. Phlorotanin: Struktur, Isolasi dan Bioaktivitas. Malang (ID): UB Press.

Firdaus M. 2013. Indeks aktivitas antioksidan ekstrak rumput laut cokelat (Sargassum aquifolium). Jurnal Pengolahan Hasil Perikanan Indonesia. 16(1): 42-47.

Grayson DH. 2000. Monoterpenoid. Ireland (IE): University Chemical Laboratory, Trinity College, Dublin 2, Ireland.

Guedes CAE, Maria ASA, Aryanna SPK, Larissa SOI, Lurdiana BD, Fernanda MAC, Antonia SGE. 2012. Antifungal activities of different extracts of marine macroalgae againts dermatophytes and candida species. Mycopathologia. 174(3): 223-232.

Habibi RA. 2017. Uji aktivitas antibakteri ekstrak kasar daun nipah (Nypa fruticans) terhadap bakteri Listeria monocytogenes dan Vibrio parahaemolyticus secara in vitro [skripsi]. Malang (ID): Universitas Brawijaya.

Harborne JB. 2006. Metode Fitokimia: Penuntun Cara Modern menganalisis Tumbuhan. Edisi IV. Kokasih P. dan I. Soediro. (penerjemah). Bandung (ID): Institut Teknologi Bandung.

Hardouin K, Burlot AS, Umami A, Tanniou A, Stiger-Pouvreau V, Widowati I, Bedoux G, Bourgougnon N. 2014. Biochemical and antiviral activities of enzymatic hydrolysates from different invasive French seaweeds. Journal of Applied Phycology. 26(2): 1029-1042.

Haryani TS, Sari BL, Triastinurmiatiningsih. 2012. Efektivitas ekstrak Padina australis sebagai antibakteri Escherichia coli penyebab diare. Fitofarmaka: Jurnal Ilmiah Farmasi. 4(2): 1-9.

Hidayat T, Nurjanah, Anwar E, Nurilmala M. 2018. Identifikasi dan karakterisasi rumput laut tropika (dari Kepulauan Seribu) sebagai sumber bahan baku kosmetik. Creative Research Journal. 4(2): 49-62.

Ibrahim S, Tse T, Yang H, Fraser A. 2009. Antibacterial activity of a crude chive extract against Salmonella in culture medium, beef broth, and chicken broth. Food Protection Trends. 29(3): 155-160.

Jawetz E, Melnick J, Adelberg E. 2007. Mikrobiologi Kedokteran. Edisi 23. Jakarta (ID): EGC.

Kordi K. 2010. A to Z Budi Daya Biota Akuatik untuk Pangan, Kosmetik dan Obat-obatan. Yogyakarta (ID): Penerbit Andi.

Kumar A, Kumari SN, Bhargavan D. 2012. Evaluation of in vitro antioxidant potential of etanolic extract from the leaves of Achyranthes aspera. Asian Journal of Pharmaceutical and Clinical Research. 5(3): 146-148.

Lim SY, Bauermeister A, Kjonaas RA, Gosh SK. 2006. Phytol-based novel adjuvants in vaccine formulation: 2 . assessment 
of efficacyin the induction of protective immune responses to lethal bacterial infections in mice. Journal of Immune Based Therapies and Vaccines. 4: 5.

Limantara L, Heriyanto. 2011. Optimasi proses ekstraksi fukosantin rumput laut cokelat Padina australis Hauck menggunakan pelarut organik polar. Ilmu Kelautan: Indonesia Journal of Marine Science. 16(2):86-94.

Manivannan K, Karthikai DG, Anantharaman P, Balasubramanian T.2011. Antimicrobial potential of selected brown seaweeds from Vedalai coastal waters, Gulf of Mannar. Asian Pacific Journal of Tropical Biomedicine. 1(2): 114-120.

Masduqi AF, Izzati M, Prihastanti E. 2014. Efek metode pengeringan terhadap kandungan bahan kimia dalam rumput laut. Buletin Anatomi dan Fisiologi. 22(1): 1-9.

Mien DJ, Carolin WA, Firhani PA. 2015. Penetapan kadar saponin pada ekstrak daun lidah mertua (Sansevieria trifasciata Prain varietas S. laurentii) secara gravimetri. Jurnal Ilmu dan Teknologi Kelautan Tropis. 2(2): 65-69.

Nasmia, Natsir S, Rosyida E. 2016. Potensi aktivitas dari ekstrak rumput laut Sargassum cinereum terhadap bakteri patogen ice ice pada Gracilaria verrucosa. Prosiding Seminar Nasional Hasil Penelitian. Lembaga Penelitian dan Pemberdayaan Masyarakat (LPPM) UNIMAS Denpasar. 1009-1017.

Nurjanah, Izzati L, Abdullah A. 2011. Aktivitas antioksidan dan komponen bioaktif kerang pisau (Solen spp). Ilmu Kelautan: Indonesia Journal of Marine Science. 16(3): 119-124.

Nursini NW. 2005. Pengaruh ekstrak jangu (Accorus calamus L.) terhadap pertumbuhan E. coli dan Vibrio cholera [Skripsi]. Jimbaran (ID): Universitas Udayana.

Park PK, Kim EY, Chu KH. 2007. Chemical disruption of yeast cells for the isolation of carotenoid pigments. Separation and Purification Technology. 53(2): 148-152.

Pratami HA, Apriliana E, Rukmono P. 2013. Identifikasi mikroorganisme pada tangan tenaga medis dan paramedis di unit perinatologi Rumah Sakit Abdul Moeloek Bandar Lampung. Medical Journal of Lampung University. 2(5): 85-94.

Pratiwi TS. 2008. Mikrobiologi Farmasi. Yogyakarta (ID): Erlangga.

Purwani E, Retnaningtyas E, Widowati D. 2012. Pengembangan model pengawet alami dari ekstrak lengkuas (Languas galanga), kunyit (Curcuma domestica) dan jahe (Zingiber officinale) sebagai pengganti formalin pada daging segar. Proceeding Biology Education Centre. 9(1): 629-634

Putra AAB, Bogoriani NW, Diantariani NP, Sumadewi NLU. 2014. Ekstraksi zat warna alam dari bonggol tanaman pisang (Musa paradiasciaca L.) dengan metode maserasi, refluks, dan sokletasi. Jurnal Kimia. 8(1): 113-119.

Radji M. 2011. Mikrobiologi Panduan Mahasiswa Farmasi dan Kedokteran. Jakarta (ID): EGC.

Rajauria G, Ghannam NA. 2013. Isolation and partial characterization of bioactive fucoxanthin from Himanthalia elongate brown seaweed: a TLC-Based approach. International Journal of Analytical Chemistry. (2013): 1-6.

Refdanita, Maksum R, Nurgani A, Endang P. 2004. Faktor yang mempengaruhi ketidaksesuaian penggunaan antibiotika dengan uji kepekaan di ruang intensif Rumah Sakit Fatmawati Jakarta Tahun 2001- 2002. Makara Kesehatan. 8(1): 2126.

Riwanti P, Izazih F. 2019. Skrining fitokimia ekstrak etanol 96\% Sargassum polycystum dan profile dengan spektrofotometri infrared. Acta Holistica Pharmaciana. 2(1): 34-41.

Robinson, Batt, Patel. 2000. Encyclopedia of Food Microbiology. San Diego (US): Academic Press.

Rohyani I, Aryanti E, Suripto. 2015. Kandungan fitokimia beberapa jenis tumbuhan lokal yang sering dimanfaatkan sebagai bahan baku obat di Pulau Lombok. Prosiding Seminar Nasional Masyarakat Biodiversitas Indonesia. 1(2): 388-391.

Rosyidah K, Nurmuhaimina, Komari, Astuti 
MD. 2010. Aktivitas antibakteri fraksi saponin dari kulit batang tumbuhan kasturi Mangifera casturi. Bioscientiae. 7 (2): 25-31.

Rukmono P, Zuraida R. 2013. Uji kepekaan antibiotik terhadap Pseudomonas aeruginosa penyebab sepsis neonatorum. Sari Pediatri. 14(5): 332-336.

Sangi MS, Momuat LI, Kumaunang M. 2012. Uji toksisitas dan skrining fitokimia tepung gabah pelepah aren (Arenga pinnata). Jurnal Ilmiah Sains. 12(2): 127134.

Setyowati WAE, Ariani SRD, Mulyani B, Rahmawati CP. 2014. Skrining fitokimia dan identifikasi komponen utama ekstrak metanol kulit durian (Durio zibethinus Murr.) varietas petruk. Seminar Nasional Kimia dan Pendidikan Kimia VI. 271280.

Siregar AF, Agus S, Delianis P. 2012. Potensi antibakteri ekstrak rumput laut terhadap bakteri penyakit kulit Pseudomonas aeruginosa, Staphylococcus epidermidis, dan Micrococcus luteus. Journal of Marine Research. 1(2): 152-160.

Sukmiwati M, Diharmi A, Mora E, Susanti E. 2018. Aktivitas antimikroba teripang kasur (Stichopus vastus Sluiter) dari Perairan Natuna Kepulauan Riau. Jurnal Pengolahan Hasil Perikanan Indonesia. 21(2): 328-335.
Suptijah P, Yanuarizki O, Nurjanah. 2013. Aktivitas antioksidan dan komponen bioaktif kerang simping (Amusium pleuronectes). Jurnal Pengolahan Hasil Perikanan Indonesia. 16(3): 242-248.

Suyono Y, Salahudin F. 2011. Identifikasi dan karakterisasi bakteri Pseudomonas pada tanah yang terindikasi terkontaminasi logam. Jurnal Biopropal Industri. 01(02): $1-2$.

Tapotubun AM. 2018. Komposisi kimia rumput laut Caulerpa lentillifera dari Perairan Kei Maluku dengan metode pengeringan berbeda. Jurnal Pengolahan Hasil Perikanan Indonesia. 21(1): 13-23.

Thangaraju N, Ventakalaksmhmi RP, Chinnasamy A, Kannaiyan P. 2012. Synthesis of silver nanoparticles and the antibacterial and anticancer activities of the crude extract of Sargassum polycystum C. Agardh. Nano Biomedicine. 4(2):89-94.

Yunianto HP, Widowati I, Radjasa OK. 2014. Skrining antibakteri ekstrak rumput laut Sargassum plagyophyllum dari Perairan Bandengan Jepara terhadap bakteri patogen Enterobacter, Pseudomonas aeruginosa dan Staphylococus aureus. Journal of Marine Science. 3(3): 165-172.

Zainuddin EN. 2006. Chemical and biological investigations of selected cyanobacteria (Blue-Green Algae [Disertasi]. Greifswald (DE): University Greifswald. 